\title{
Gelatin model for training ultrasound-guided puncture
}

\author{
Treinamento de punção ecoguiada em modelo de gelatina
}

\author{
Alexandre Campos Moraes Amato', Stephanie Lopes de Freitas', Patrícia Maquinêz Veloso', \\ Tamara Cristine Vieira Correia', Ricardo Virginio dos Santos' ${ }^{1}$ Salvador José de Toledo Arruda Amato 2
}

\begin{abstract}
Background: $\mathrm{It}$ is indispensable that members of the medical profession receive the technical training needed to enable them to rapidly obtain effective vascular access. Training procedures should be used judiciously to familiarize students with the technique. However, existing models are expensive or ineffective, and models need to be developed that are similar to what will be encountered in real patients. Objectives: To demonstrate creation and application of a gelatin model for training ultrasound-guided puncture. Methos: The model was made using a mixture of colorless gelatin and water in a transparent plastic receptacle with two pairs of orifices of different diameters, through which two plastic tubes were inserted, to simulate blood vessels. Results: The model was a close approximation to the real medical procedure in several aspects, since gelatin has a similar consistency to human tissues, providing a more faithful reproduction of the tactile sensation at the moment when the needle reaches the interior of a vessel and its contents are aspirated. Conclusions: The method proposed here can be used to easily construct a low-cost model using everyday materials that is suitable for large-scale training of ultrasound-guided puncture.
\end{abstract}

Keywords: training; interventional ultrasonography; ultrasonography.

\begin{abstract}
Resumo
Contexto: É imprescindível a capacitação técnica da classe médica para a obtenção de um acesso vascular rápido e eficiente, sendo que os procedimentos de treinamento devem ser usados sabiamente como forma de familiarizar o aluno à técnica. Os modelos comerciais existentes são de alto custo ou não são eficientes, devendo ser criados novos modelos semelhantes ao que será visto num paciente. Objetivos: Demonstrar a criação e a utilização de um modelo de gelatina para o treinamento da punção ecoguiada por ultrassom. Métodos: Modelo criado através da mistura de água com gelatina incolor num recipiente plástico transparente com dois orifícios de diferentes diâmetros, nos quais foram colocados dois canos plásticos simulando os vasos sanguíneos. Resultados: $O$ modelo proposto se aproxima da realidade do procedimento médico em vários aspectos, pois a consistência da gelatina é próxima aos tecidos humanos, promovendo a preservação da sensação tátil ao atingir o interior do vaso e durante a aspiração do conteúdo. Conclusões: $O$ método proposto permite criar um modelo de baixo custo e fácil confecção utilizando-se materiais de uso cotidiano para treino de punção ecoguiada em larga escala.
\end{abstract}

Palavras-chave: capacitação; ultrassonografia de intervenção; ultrassonografia. 


\section{INTRODUCTION}

Vascular access is used for administration of fluids and drugs as part of advanced life support, but it can be difficult to achieve in critically ill patients and so it is indispensable that members of the medical profession receive the technical training needed to enable them to rapidly obtain effective vascular access. ${ }^{1}$

In the United States, around 5 million central venous punctures are performed annually, with a complication rate of about $15 \%$. The high incidence of adoption of this procedure means that it is extremely important to prevent its possible complications, which account for around 750,000 adverse events per year, according to American data. Possible complications that can involve serious risk to patients include pneumothorax, arterial puncture; hematoma; and injuries to the phrenic nerve and stellate ganglion. ${ }^{2-4}$

One of the most important factors influencing the success of this procedure is the experience of the professionals involved. Traditionally anatomic landmarks are used when performing central venous punctures, meaning that anatomic variations can make the procedure more difficult. Since 2001, the Agency for Healthcare Research and Quality has recommended 11 practices to improve the safety of care provided to patients undergoing surgery and/or admitted to hospital, one of which is using ultrasound to guide central venous punctures, increasing safety and minimizing risks. ${ }^{2-6}$

Training procedures should be used wisely to familiarize students with the technique, but existing models are expensive or ineffective, since an ideal training model should be similar to what will be encountered in real patients. The objective of this study was to develop an inexpensive and realistic model that is capable of simulating a routine procedure, which is a real challenge. ${ }^{7,8}$

\section{MATERIALS AND METHODS}

The materials needed for the proposed model are as follows (Table 1): $300 \mathrm{~g}$ of colorless and flavorless gelatin; $1200 \mathrm{ml}$ of hot water; one 1.8 liter plastic receptacle; one perforated plastic receptacle; a drill; 2 hole cutters of different sizes; 2 plastic tubes with diameters similar to the hole cutters; a mixer; hot glue; a spoon; a refrigerator.

Preparation of the model involves the following steps: Two orifices of different sizes are made in each side of one plastic receptacle (four orifices in total) with the hole cutters (Figure 1A) and two plastic tubes are introduced into these orifices so that they traverse the receptacle completely (Figure 1B).
Table 1. List of materials employed.

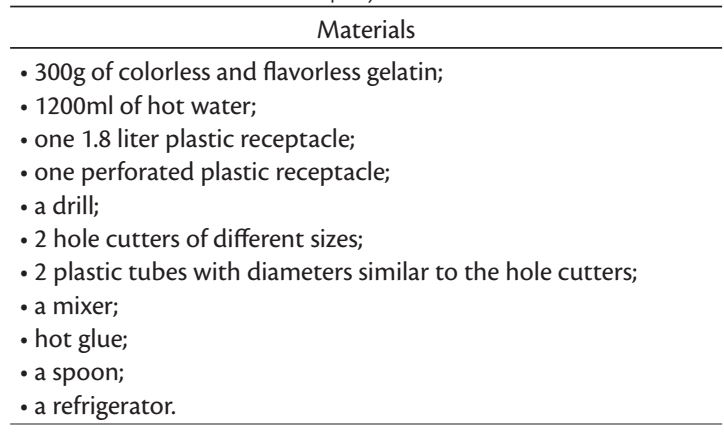

These orifices are sealed around the tubes with hot glue to avoid leakage. The water is heated and gently mixed with the gelatin; the dissolving process can be expedited using a mixer (Figure 1C). A spoon is used to remove all air bubbles before the gelatin hardens. The gelatin is poured into the receptacle and placed in the refrigerator until it hardens (Figure 1D). A spoon is used to remove any remaining air bubbles as the gelatin hardens. Once the gelatin has set, the tubes are carefully removed and then the gelatin is removed from the receptacle, placed into the other receptacle with no holes, which is filled with water. The orifices in the gelatin fill with water, simulating blood inside the vessels (Figure 2$)^{9}$.

\section{RESULTS}

The model exhibited an acceptable consistency for realistic representation of human tissues during ultrasound-guided puncture training. The combination of the shape chosen for the model and its consistency resulted in ultrasound images similar to a simplified normal anatomy, and the adjacent tissues, the vessel lumen and its liquid contents and the refractive vessel wall were all clearly identifiable. Furthermore, the material's partial transparency also offered an external view of the puncture procedure, further aiding in understanding of the Seldinger technique (Figures 2, 3 and 4).

\section{DISCUSSION}

Central venous access is an extremely important procedure in medical practice, it demands skill and anatomic knowledge and is a potential cause of serious complications. Using ultrasound for central venous access makes it possible to assess the location and diameter of vessels, facilitating insertion and/or choice of puncture site since it provides direct view of the progress of the needle and guidewire. The addition of imaging reduces the number of puncture attempts, improves insertion success rates, 

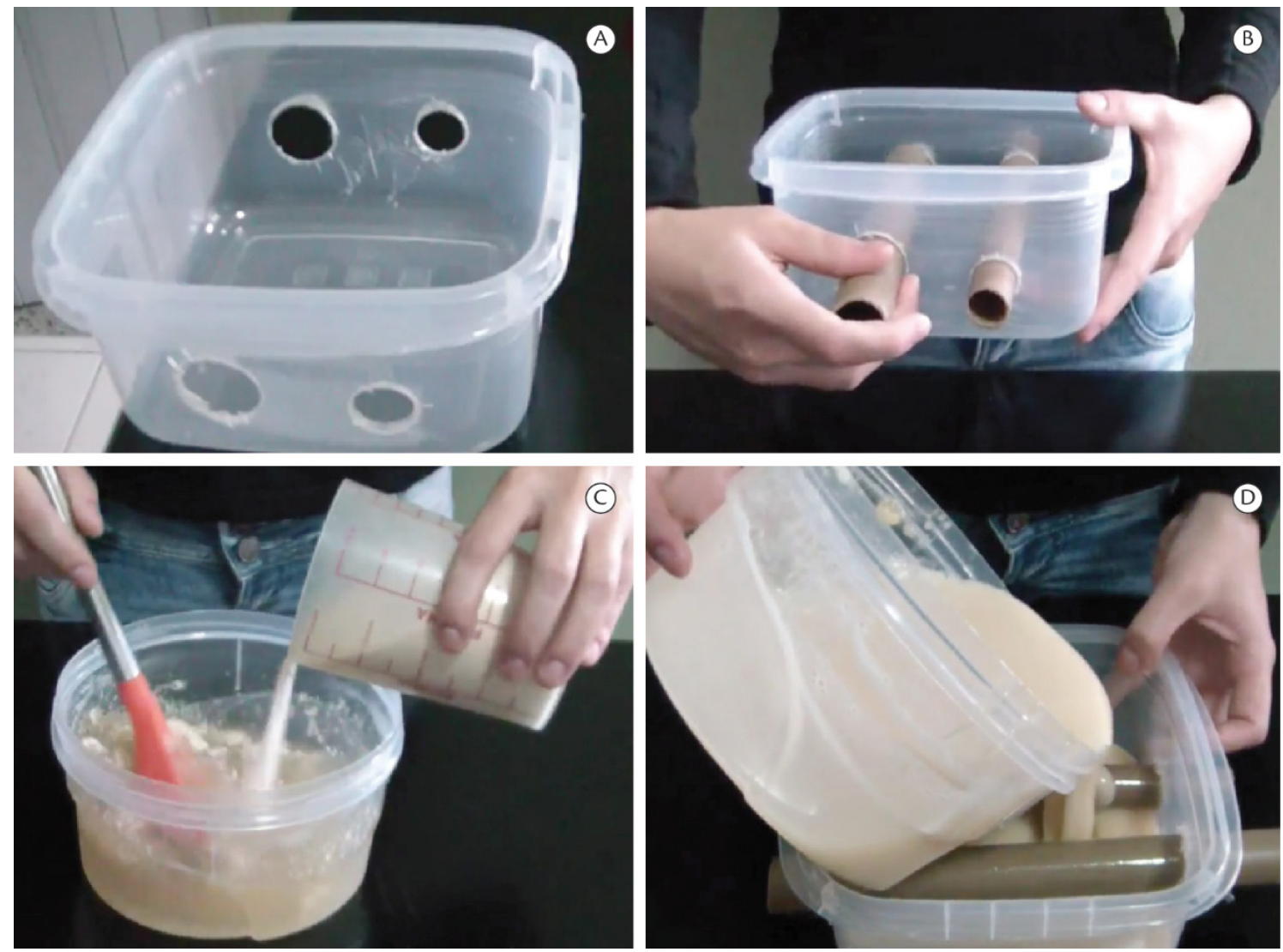

Figure 1. Construction of model: A) receptacle with pairs of orifices on opposite sides: in the example above four orifices were made to fit two tubes; B) two tubes passing through the orifices in the receptacle; C) mixing the ingredients; D) prepared gelatin is put into the receptacle.

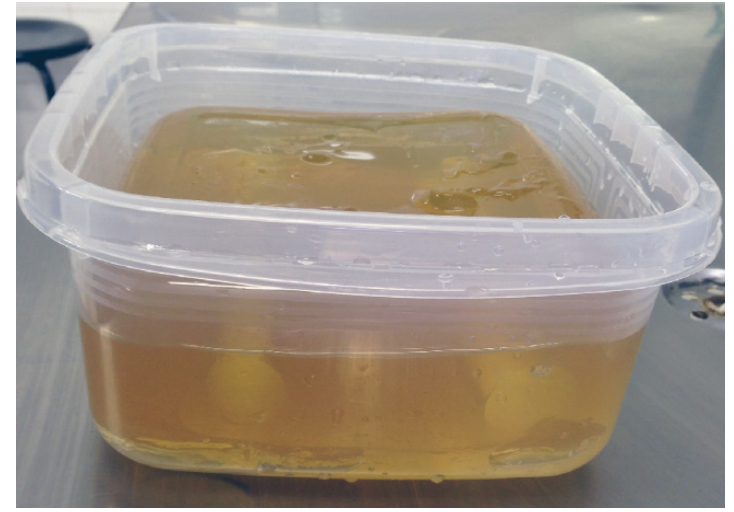

Figure 2. Final result: Gelatin model of blood vessels.

minimizes catheter-related complications and reduces insertion time, particularly in patients with difficult vascular access. ${ }^{10}$

Many models have been developed with the aim of simulating medical procedures, but the majority of them bear very little similarity to what is found in real patients. ${ }^{11,12}$ With the aim of improving the range of models available, by achieving a closer approximation to reality, this study consisted of creation of a model made from gelatin that could be used to train ultrasound-guided punctures, both transversally and longitudinally.

It was found that the model was indeed a close approximation to the real medical procedure (Figures 3 and 4), since gelatin has a similar consistency to human tissues, in addition to providing a more faithful reproduction of the moment at which a real needle enters the interior of a vessel and its contents are aspirated. The ultrasound image showed the primary structures, such as lumen and adjacent tissues, both in transverse and in longitudinal mode. The model can be used to teach some of the most important points of the ultrasound-guided puncture technique that must be taught with care, such as puncture with a transverse scan, puncture with a longitudinal scan, identifying the needle on Doppler ultrasonography, observation of the structural change and transmission of vibration as the needle progresses. However, this model cannot be used to teach the anatomic landmarks, to show how to observe blood flow, or to demonstrate venous collapse or arterial pulsation. 


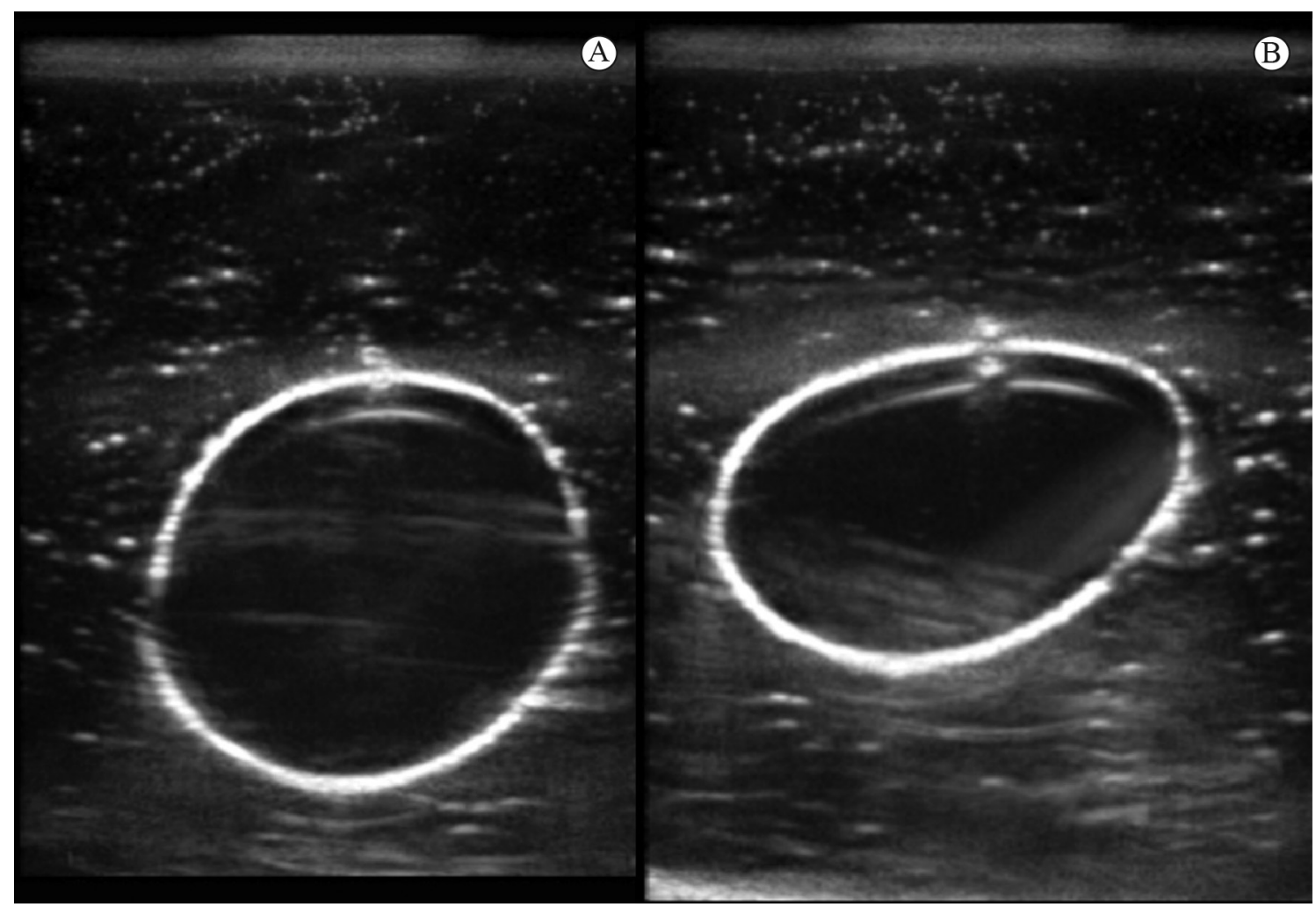

Figure 3. Ultrasound of resulting model: transverse image. A) without compression; B) with compression similar to that of arteries.

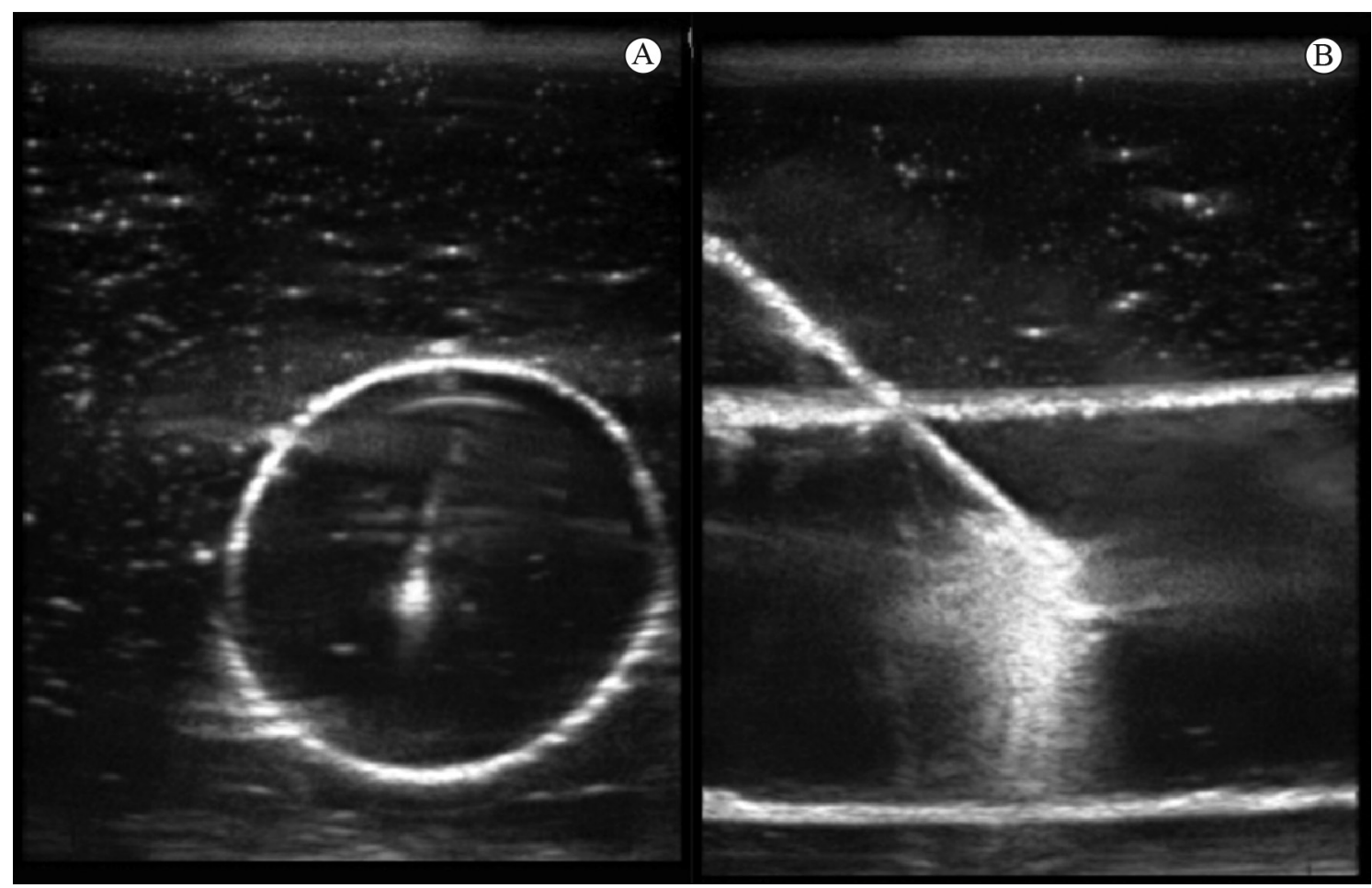

Figure 4. Model in use: Mode B ultrasonographic images: A) transverse image showing the needle in the center of the vessel; B) longitudinal image showing the path taken by the needle to reach the vessel interior. 
Additionally, although the echogenicity of gelatin is similar to human tissues, there is no differentiation of structures adjacent to the vessel, such as arteries, nerves and muscles (Figures 3 and 4).

\section{CONCLUSIONS}

The method proposed here allows production of a low-cost (approximately R $\$ 55.00$ or US\$17.00) and easy to construct model for large-scale basic training in ultrasound-guided puncture from everyday materials, making it possible to simulate a procedure that is part of daily routine, but is also of extreme importance, in medical practice.

\section{REFERENCES}

1. Carlotti APCP. Acesso vascular. Medicina. 2012;45(2):208-14.

2. Dexheimer FL No., Teixeira C, Oliveira RP. Acesso venoso central guiado por ultrassom: qual a evidência? Rev Bras Ter Intensiva. 2011;23(2):217-21. PMid:25299723.

3. Kusminsky RE. Complications of central venous catheterization. J Am Coll Surg. 2007;204(4):681-96. http://dx.doi.org/10.1016/j. jamcollsurg.2007.01.039. PMid:17382229.

4. Wollmeister J, Conceição DB, Helayel PE, Santos RK. Ultrasoundguided central venous puncture in an obese patient with cervical adenomegaly. Rev Bras Anestesiol. 2008;58(4):403-8. PMid:19378590.

5. Lamperti $M$, Bodenham $A R$, Pittiruti $M$, et al. International evidence-based recommendations on ultrasound-guided vascular access. Intensive Care Med. 2012;38(7):1105-17. http://dx.doi. org/10.1007/s00134-012-2597-x. PMid:22614241.

6. Ault MJ, Rosen BT, Ault B. The use of tissue models for vascular access training. Phase I of the procedural patient safety initiative.J Gen Intern Med. 2006;21(5):514-7. http://dx.doi.org/10.1111/j.15251497.2006.00440.x. PMid:16704401.

7. Garrood T, lyer A, Gray K, et al. A structured course teaching junior doctors invasive medical procedures results in sustained improvements in self-reported confidence. Clin Med. 2010;10(5):464-7. http://dx.doi.org/10.7861/clinmedicine.10-5-464. PMid:21117378.

8. Macnab AJ, Macnab M. Teaching pediatric procedures: the Vancouver model for instructing Seldinger's technique of central venous access via the femoral vein. Pediatrics. 1999;103(1):E8. http://dx.doi.org/10.1542/peds.103.1.e8. PMid:9917488.
9. Vascular: Cirurgia Vascular e Endovascular [site na Internet] Punção ecoguiada na UNISA. 2014. [atualizado 2014 nov 18; citado 2014 dez 03]. http://vascular.cc/modelo.html

10. Flato UAP, Petisco GM, Santos FB. Ultrasound-guided venous cannullation in critical care unit. Rev Bras Ter Intensiva. 2009;21(2):190-6. http:// dx.doi.org/10.1590/S0103-507X2009000200012. PMid:25303350.

11. Miranda RB, Nardino EP, Gomes T, Farias P. Nova técnica para treinamento em acessos vasculares guiados por ultrassom utilizando modelo de tecido animal. J Vasc Bras. 2012;11(1):83-7.

12. Denadai R, Saad-Hossne R, Todelo AP, Kirylko L, Souto LR. Low-fidelity bench models for basic surgical skills training during undergraduate medical education. Rev Col Bras Cir. 2014;41(2):137-45. http:// dx.doi.org/10.1590/S0100-69912014000200012. PMid:24918729.

Correspondence Alexandre Campos Moraes Amato Universidade de Santo Amaro - Unisa Av. Brasil, 2283 - Jardim América CEP 01431-001 - São Paulo (SP), Brazi Tel.: +55 (11) 5053-2222 E-mail:dr.alexandre@amato.com.br

Author information

ACMA - Professor of Vascular Surgery at Universidade de Santo Amaro (Unisa); member of Sociedade Brasileira de Angiologia e Cirurgia Vascular; board certified in Vascular and Endovascular Surgery by Sociedade Brasileira de Angiologia e Cirurgia Vascular; and board certified in Doppler Ultrasound by Colégio Brasileiro de Radiologia.

SLF, PMV and TCVC - Medical students at Universidade de Santo Amaro (Unisa) RVS - professor of Vascular Surgery at Universidade de Santo Amaro (Unisa).

SJTAA - chief of the vascular team at Amato - Instituto de Medicina Avançada.

Author contributions Conception and design: ACMA, SLF Analysis and interpretation: ACMA Data collection: ACMA, SLF, PMV, TCVC, RVS Writing the article: ACMA, SLF, PMV, TCVC, RVS Critical revision of the article: ACMA, SJTAA Final approval of the article*: ACMA, SLF, PMV, TCVC, RVS, SJTAA Statistical analysis: N/A Overall responsibility: ACMA

*All authors have read and approved of the final version of the article submitted to J Vasc Bras. 